\title{
Density and temperature dependent feeding rates in an established and an alien freshwater gammarid fed on chironomid larvae
}

\author{
Gerhard MAIER ${ }^{1,2) *}$, Axel KLEY ${ }^{1)}$, Yasmin SCHANK ${ }^{3)}$, Monika MAIER ${ }^{2)}$, Gerd MAYER $^{4)}$ and Dieter WALOSZEK ${ }^{4)}$ \\ ${ }^{1)}$ Department of Experimental Ecology, University of Ulm, Albert-Einstein-Allee 11, 89069 Ulm, Germany \\ ${ }^{2)}$ Bureau of Aquatic Ecology, Brucknerstr. 23, 89250 Senden, Germany \\ ${ }^{3)}$ School of Applied Sciences, Weihenstephan, Department Triesdorf, Steingruberstrasse 2, 91746 Weidenbach, Germany \\ ${ }^{4)}$ Biosystematic Documentation, University of Ulm, Helmholtzstrasse 20, D-89081 Ulm, Germany \\ *e-mail corresponding author:gmaier-senden@t-online.de
}

\begin{abstract}
We compared feeding rates of the well-established, non-invasive amphipod Gammarus roeselii with those of the invasive Dikerogammarus villosus at different prey densities and different temperatures in laboratory experiments using chironomid larvae as prey. Feeding rates were very variable in both species but higher in the invader species than in the well-established non-invasive species. These results were age independent. At high temperature $\left(18-20^{\circ} \mathrm{C}\right)$ and high prey density $\left(\geq 1000\right.$ prey $\left.\mathrm{m}^{-2}\right)$ one large adult D. villosus consumed 6-9 prey day ${ }^{-1}$ on average while one $\mathrm{G}$. roeselii consumed 4-7 prey $d^{-1}$ and one smaller $\mathrm{D}$. villosus of a length of 8-10 mm consumed 2-5 prey $d^{-1}$ while one G. roeselii of the same length consumed 3 prey $d^{-1}$. Predation rate decreased considerably from high $\left(18-20^{\circ} \mathrm{C}\right)$ to low temperature $\left(3 \pm 2{ }^{\circ} \mathrm{C}\right)$, from 9 to 4 prey predator ${ }^{-1} d^{-1}$ in $\mathrm{D}$. villosus and from 7.5 to 2.5 prey predator ${ }^{-1} d^{-1}$ in $\mathrm{G}$. roeselii. We conclude that both gammarids consumed a biomass in the range of 1/2 to $1 / 3$ to their own biomass and that low predation/feeding rate at low temperature could be a reason why, in some places, indigenous gammarids can re-colonize their former habitats for a short period of time in cold winter and early spring in spite of the presence of the invasive. We further conclude that differences in weight between the species in particular in the experiments with adults can have influenced feeding rates; possibly differences in weight-specific feeding rates are small.
\end{abstract}

Key words: consumption rates, carnivory, Dikerogammarus villosus, Gammarus roeselii, prey density, temperature

\section{INTRODUCTION}

Formerly, freshwater gammarids were considered as representatives of the functional feeding group of shredders, feeding primarily on fallen leaves and particulate microbia- enriched organic matter (Bärlocher \& Kendrick 1973; Haeckel et al. 1973; Kostalos \& Seymour 1976; Cummins \& Klug 1979). More recent investigations of feeding ecology, morphology and biomarkers have shown that freshwater gammarids are omnivorous, feeding on a variety of food (Dick 1996; MacNeil et al. 1997; Dick \& Platvoet 1996, 2000; Krisp \& Maier 2005; Platvoet et al. 2006; Maazouzi et al. 2007; Mayer et al. 2008). Although omnivory seems widespread in freshwater gammarids, differences in preferred food types or feeding modes seem likely. This has already been observed by Ponyi $(1956,1961)$ who distinguished between "filter feeding" amphipods and "chewing" ones. More recent investigations have shown that several gammarids can be markedly carnivorous (e.g., MacNeil et al. 1997).

The Ponto-Caspian amphipod Dikerogammarus villosus Sowinsky, 1894 began invading large rivers of Central Europe in the 1990s (Bij de Vaate \& Klink 1995; Grabow et al. 1998). Meanwhile the species is recorded from various large lakes, e.g., Lake Constance, Germany and lakes in adjacent countries, Lake Leman and Lake Geneva, Switzerland or Lake Garda, Italy (e.g., Mürle et al. 2002; Bollache 2004; Lods-Crozet \& Reymond 2006; Casellato et al. 2006). Coincidently with the arrival of $D$. villosus a decline of several native macro-invertebrates, including native and established gammarids such as Gammarus roeselii Gervais, 1835, was observed (Bollache et al. 2004; Kley \& Maier 2006; van Riel et al. 2006). Laboratory studies suggested that $D$. villosus is markedly carnivorous feeding on a variety of prey types from different taxonomic groups (Dick et al. 2002; Krisp \& Maier 2005). Isotope analyses even suggested that $D$. villosus could be placed on the same trophic level as some fish species (Marguillier 1998). Although numerous investigations demonstrated that, besides feeding on leaves and detritus, freshwater gammarids are cannibals and predators (e.g., reviewed in MacNeil et al. 1997) little is known about the quantity of prey one gammarid can consume per time unit. Krisp \& Maier (2005) studied the consumption rate of four gammarid species at high prey density and observed that each individual of these gammarids consumed prey of approximately one third of its own biomass per day.

To shed more light into the feeding rate question, we conducted laboratory experiments about feeding of two gammarid species, the well-established $G$. roeselii and the invasive, alien $D$. villosus, at different prey densities 
and different temperatures. We chose chironomid larvae since these belong to the preferred prey organisms of gammarids and since they are consumed entirely (Dick et al. 2002; Krisp \& Maier 2005). Our expectation was that feeding rate is particularly high in the invasive $D$. villosus since this species is known to exert a high impact on native food webs (van Riel et al. 2006). We also expected that the feeding rate of both gammarid species decreases considerably at low temperature. A decrease in feeding rate of $D$. villosus at low temperature could explain that native gammarids, which were displaced by the invasive in many places, can sometimes re-colonize their former habitats for a short time in cold winters and early springs.

\section{METHODS}

Specimens of $D$. villosus were collected at the shore of Lake Constance near Langenargen (E 9०31'57"; N $\left.47^{\circ} 36^{\prime} 07^{\prime \prime}\right)$, G. roeselii was obtained from the Danube near Ulm (E $\left.10^{\circ} 2^{\prime} ; \mathrm{N} 48^{\circ} 25^{\prime}\right)$. Upon capture by nets, the individuals were immediately transported to the laboratory, sorted by species and kept at densities similar to that at the collection sites $\left(250-350\right.$ ind $\left.\mathrm{L}^{-1}\right)$ in aerated plastic containers $(50 \times 40 \times 40 \mathrm{~cm})$. Gammarids, which were used in high-temperature experiments, were maintained at $18-20^{\circ} \mathrm{C}$, those used in low temperature experiments were kept at $8-10$ and $2-3{ }^{\circ} \mathrm{C}$, respectively. All containers contained aged tap water and were equipped with substrate (gravel and stones with a grain size of 1-3 cm). Dried leaves of alder and living chironomid larvae served as food. Animals which were used in the high-temperature experiments were kept under long-day conditions (approximately 14:10 h light:dark), those which were used in the low-temperature experiments were kept under short-day conditions (approximately 8:16 h light:dark). Chironomid larvae were collected from their natural habitat (generally in the Danube, near Ulm) or bought in aquarium trade, dependent on their availability in the nature. The larvae were kept under the same temperature and light conditions as the gammarids but in smaller plastic boxes (12 $\times 12 \times 6 \mathrm{~cm})$ at densities that were in the range of densities observed in nature (200-500 ind $\left.\mathrm{m}^{-2}\right)$. Chironomids were collected (or bought) one or two days before they were used in experiments. Only larvae of a body length of $10( \pm 2) \mathrm{mm}$ and only those who appeared healthy were used in an experiment.

Experiments were run in boxes of the same size than those, which were used to maintain chironomid larvae. The boxes were provided with stones (grain size: 1-3 $\mathrm{cm}$ ) and/or filter tubes (length: $1 \mathrm{~cm}$, diameter of holes: $0.5 \mathrm{~cm}$ ) and filled with tap water to a height of $5 \mathrm{~cm}$. In a first series of experiments, two adult gammarids of $D$. villosus or $G$. roeselii (total length: $>12 \mathrm{~mm}$; not size matched) were introduced into a box containing water of $18-20{ }^{\circ} \mathrm{C}$ and allowed to acclimatize to experimental conditions for $2 \mathrm{~d}$. After that time, during which the gammarids were starved, prey organisms were added. Five different prey densities $(5,10,15,20$ and 25 specimens corresponding to approximately 500, 1000, 1500, 2000 and 2500 ind $\mathrm{m}^{-2}$ ) were tested. During an exposition time of $24 \mathrm{~h}$, the gammarids were allowed to feed; then they were removed and the remaining chironomids were counted. In a second set of experiments size-matched smaller individuals (total body length: 8$10 \mathrm{~mm}$ ) of $G$. roeselii and D. villosus were used as predators. The experimental design was the same as in the experiments with large adults but feeding rate was tested at three different prey densities $(5,10$ and 15 chironomid larvae per box) only. In a third set of experiments feeding rate was tested at low water temperature. Adult specimens (total length: 14-18 mm) of both gammarid species, which had been collected and maintained at low temperature and short day conditions (see above), were allowed to feed on chironomid larvae at two low temperatures ( 8 and $3{ }^{\circ} \mathrm{C} \pm 2^{\circ} \mathrm{C}$, respectively). Prey density in the temperature experiments was $2000 \mathrm{~m}^{-2}$. In total 509 experiments (311 with adults, 89 with juveniles and 109 at low temperature) were conducted. In all experiments, gammarids of both sexes were used randomly.

A non-parametric Kruskal-Wallis ANOVA served to test for differences in feeding rate at different prey densities and temperatures. A Wilcoxon test was used to test for differences in feeding rate between species.

\section{RESULTS}

Feeding rate of adults of both gammarid species was very variable but depended on prey density (Kruskal-Wallis ANOVA; D. villosus: $\mathrm{H}=75.0_{(4)}, \mathrm{P}$ $<0.0001$; G. roeseli: $\left.\mathrm{H}=18.1_{(4)}, \mathrm{P}<0.0002\right)$. Consumption rate of large adult $D$. villosus was significantly higher than consumption rate of adult $G$. roeselii (Wilcoxon: $\mathrm{Z}=-6.53, \mathrm{P}<0.0001)$. One adult $D$. villosus consumed approximately between 6 and 9 chironomid larvae $\mathrm{d}^{-1}$ on average at a prey density $\geq 1000 \mathrm{~m}^{-2}$ while one adult $G$. roeselii generally consumed between 4 and 7 larvae on average at a prey density of $\geq 1000 \mathrm{~m}^{-2}$ (Fig. 1).

Consumption rate of specimens of a length of 8-10 $\mathrm{mm}$ also depended on prey density (Kruskal-Wallis ANOVA: D. villosus: $\mathrm{H}=17.3_{(2)}, \mathrm{P}<0.0002 ; G$. roeselii: $\left.\mathrm{H}=20.8_{(2)}, \mathrm{P}<0.0001\right)$. Specimens of $D$. villosus also consumed more prey than G. roeselii specimens (Wilcoxon: $\mathrm{Z}=-2.72, \mathrm{P}<0.007)$. Again consumption rate was very variable (Fig. 2). At high density $(\geq 1000$ prey $\mathrm{m}^{-2}$ ), specimens of $D$. villosus consumed 2 and 5 prey $\mathrm{d}^{-1}$ on average while $G$. roeselii consumed 3 prey $\mathrm{d}^{-1}$.

Feeding rate strongly depended on temperature in both species (Kruskal-Wallis ANOVA: D. villosus: $\mathrm{H}=$ $41.7_{(2)}, \mathrm{P}<0.0001$; G. roeselii: $\left.\mathrm{H}=37.7_{(2)}, \mathrm{P}<0.0001\right)$. In $D$. villosus, feeding rate decreased from approximately 9 prey predator ${ }^{-1} \mathrm{~d}^{-1}$ at $18-20{ }^{\circ} \mathrm{C}$ to 4 prey predator $^{-1} \mathrm{~d}^{-1}$ at $3{ }^{\circ} \mathrm{C}$ and in G. roeselii from 7.5 prey 

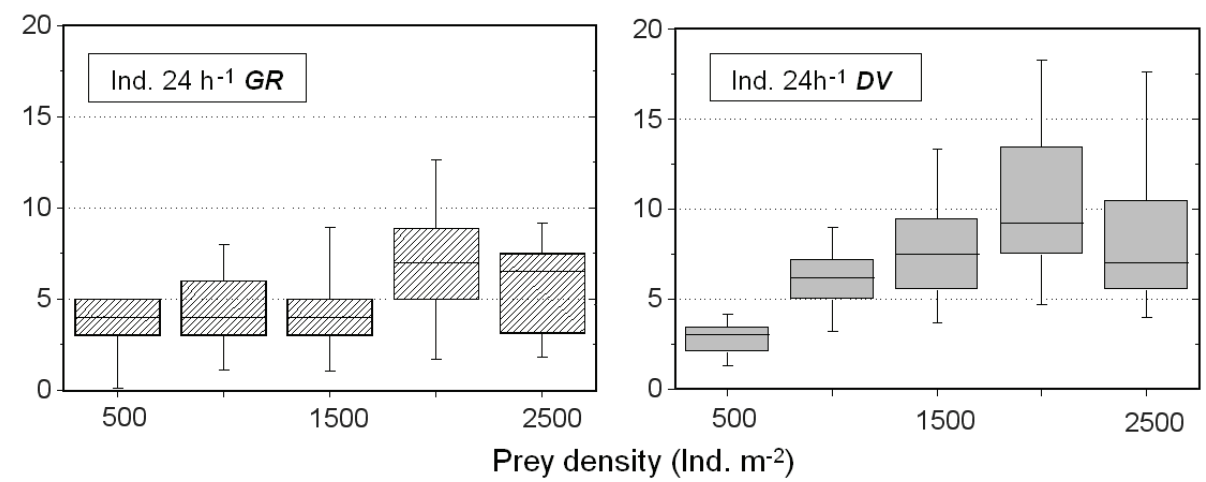

Fig. 1. Consumption rate of adult Gammarus roeselii GR and Dikerogammarus villosus DV (size $>12 \mathrm{~mm}$ ) at 5 different densities of chironomid larvae.

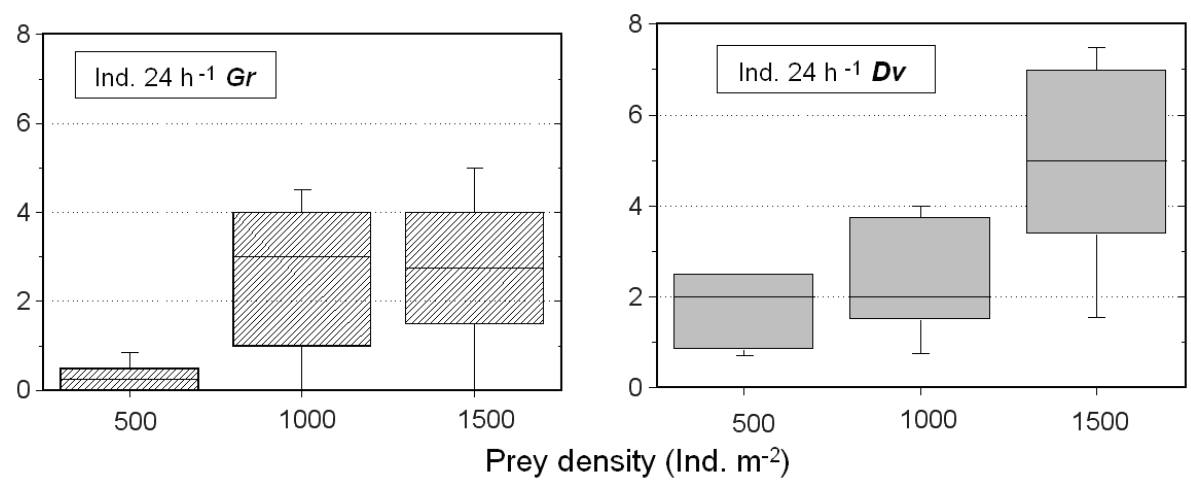

Fig. 2. Consumption rate of size matched 8-10 mm individuals of Gammarus roeselii $\mathrm{Gr}$ and Dikerogammarus villosus Dv at 3 different densities of chironomid larvae.
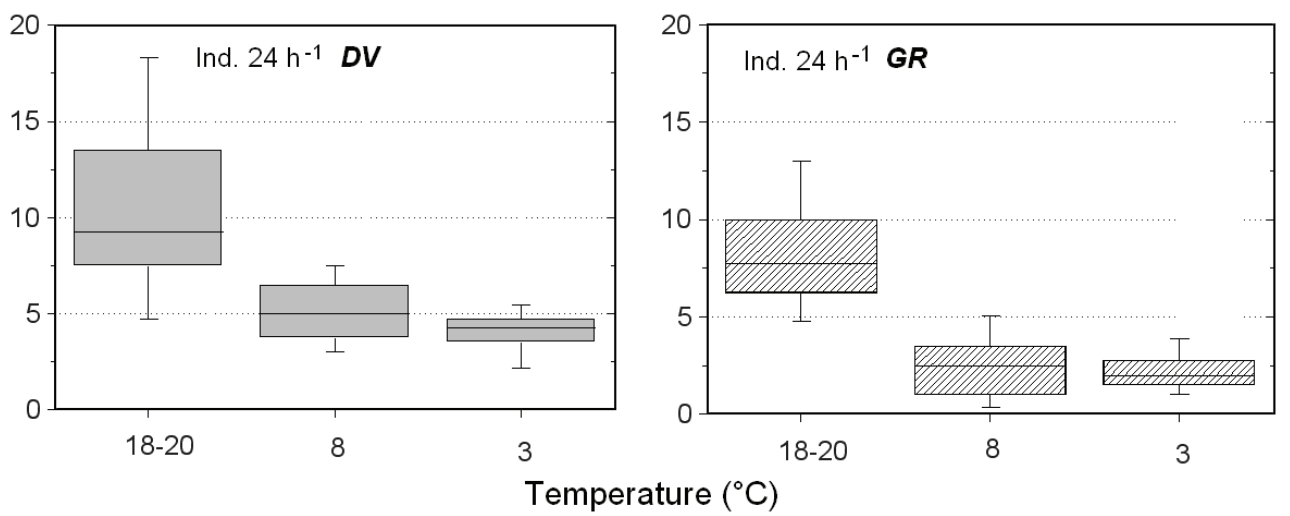

Fig. 3. Consumption of large adult specimens of Gammarus roeselii GR and Dikerogammarus villosus DV fed chironomid larvae at 3 different temperatures.

predator ${ }^{-1} \mathrm{~d}^{-1}$ at $18-20{ }^{\circ} \mathrm{C}$ to 2 prey predator ${ }^{-1} \mathrm{~d}^{-1}$ at $3{ }^{\circ} \mathrm{C}$ (Fig. 3).

\section{DISCUSSION}

Our results show that both gammarids consumed considerable amounts of prey at least at high water temperature and prey density, which highlights the findings of many authors during the last decade that gammarids can be markedly carnivorous. That $D$. villosus, which is known for its predatory habit (e.g., Dick \& Platvoet 2000; Dick et al. 2002; Krisp \& Maier 2005; van Riel et al. 2006), consumed slightly more prey than G. roeselii was expected. Recent investigation of mouthpart morphology indicated that, although both species have tools for carnivorous feeding, G. roeselii is more adapted to feed on plant material and adherent food (Mayer et al. 2009). This species has, unlike $D$. villosus, chisel-like cuspidate setae on the endites of its maxillulae and specialized setae on the maxillipeds, which are suited for scraping off adherent algae from plants or the substrate; its mandibular molars have rasp-like structures on the surfaces, which are well suited for grinding firm plant 


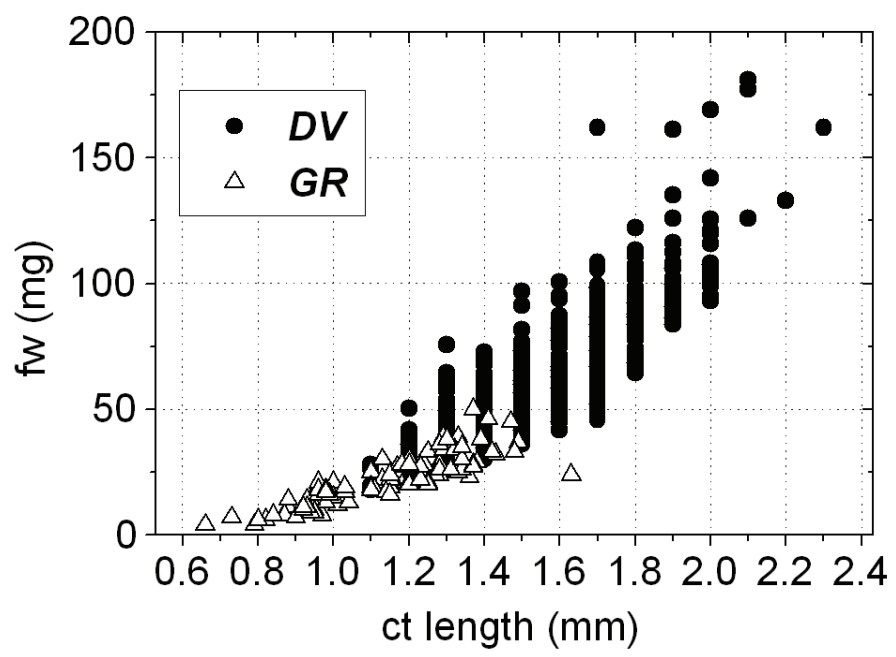

Fig. 4. Length from the anterior margin of the cephalothorax until the posterior margin of the third pleomer (ct) versus fresh weight (fw) of randomly selected adult specimens of Gammarus roeselii (open symbols) and Dikerogammarus villosus (full symbols).

material, whereas those of $D$. villosus are only little structured (Mayer et al. 2009). Platvoet et al. (2006), who studied $D$. villosus feeding on micro-algae, found intact algae in its foregut, which supports the opinion that the species has no tools for grinding plant material. The specialization to a more herbivorous mode of feeding in $G$. roeselii may explain the somewhat lower feeding rate of this species compared to that of $D$. villosus when only animal prey is present. Moreover, the higher consumption rate in large adult $D$. villosus compared to adult $G$. roeselii may originate from the higher food demand of the former species which per se originates from its greater body mass. Although in our experiments with large adults we tried to use individuals of similar size, $D$. villosus individuals, in overall, were most probably larger on average than individuals of $G$. roeselii. We did not analyse fresh weights of test specimens because handling during the weighing can lead to injuries. Adult specimens of $D$. villosus can have fresh weights of approximately $80 \mathrm{mg}$ in female to $120 \mathrm{mg}$ in male sex (Kley \& Maier 2006; Pöckl 2007) or even higher (Kley \& Maier 2003), while in G. roeselii the fresh weights can rise to only 60 and $90 \mathrm{mg}$, respectively (Pöckl 1993, 1995). It is, therefore, most probable that differences in weights between large adult specimens of the two species may have influenced feeding rates. Further, we do not know whether the proportion of males, which are more carnivorous than females (Kinzler \& Maier 2003), was the same in G. roeselii and in $D$. villosus test specimens because we did not distinguish between sexes in our experiments. Gergs \& Rothhaupt (2008) studied feeding rate, assimilation efficiencies and growth of $G$. roeselii and $D$. villosus using chironomid larvae, bio-deposited material from zebra mussels and alder leaves as food. These authors found that weight-specific feeding rate of $G$. roeselii on chironomid larvae was higher than weight-specific feeding rate of $D$. villosus on the same prey. Yet, as we in our study, they did not distinguish between males and females. Differences in feeding rate between sexes should be considered more strongly in future experiments. Another difference between our study and that of Gergs \& Rothhaupt (2008) is that we used living chironomid larvae while the latter authors used dead (commercially available frozen) larvae. Possibly usage of dead larvae compared to usage of living larvae may have an effect on consumption rate of both gammarids. Kinzler \& Maier (2006) showed that $G$. roeselii is more active than $D$. villosus. High activity in $G$. roeselii may result in high encounter rates with the prey and differences in this effect between species may be greater when using dead, larvae compared to when using conspicuous, moving ones.

The fact that in the experiments with size-matched smaller specimens, $D$. villosus also consumed more prey than $G$. roeselii suggests that feeding rate differences between species were not simply an effect of size but also an effect of the more predacious habit of $D$. villosus. This assumption is supported by earlier investigations, in which $D$. villosus showed a remarkable broad prey spectrum encompassing macro-invertebrates from various taxonomic groups (Dick et al. 2002; van Riel et al. 2006). Gammarus roeselii instead seems to be limited to more soft-bodied invertebrates, such as some dipteran larvae (Krisp \& Maier 2005). However, results of weighing of males and females indicated that $D$. villosus specimens are slightly heavier than $G$. roeselii specimens of the same size (Fig. 4). Thus the observed differences in feeding rate between the test species may be lower when referring to a weight basis.

Consumption rates reported here are within the range of consumption rates reported in the literature. Roberts (1995), e.g., reported that Gammarus duebeni killed 4-8 mosquito larvae day ${ }^{-1}$ under laboratory conditions; Krisp \& Maier (2005) showed that D. villosus consumed on average 7 chironomid larvae day ${ }^{-1}$ while 
G. roeselii consumed only three larvae day ${ }^{-1}$ at a prey density of approximately 700 individuals $\mathrm{m}^{-2}$. Echinogammarus ischnus, a further non-indigenous species originating from the Ponto-Caspian Region, and the native species Gammarus pulex had intermediating consumption rates (Krisp \& Maier 2005). That the feeding rate decreased with decreasing temperature was also expected since it is a commonplace in invertebrates. Van der Velde et al. (2009) also observed lower consumption rates in three gammarid species in winter compared to consumption rates in the warm season. Low predation rate of $D$. villosus at low temperature may be the reason that native gammarids are sometimes able to re-colonize their former habitat for a short time in the cold season. We occasionally observed small numbers of native gammarids in the River Danube in early spring. These native gammarids, which may have migrated from tributaries during winter were subsequently displaced by $D$. villosus so that no or only few specimens were present in late spring / early summer.

Taking into account the above described weights of gammarids together with the observation that one chironomid larva of $1 \mathrm{~cm}$ length has a mean fresh weight of approximately $3.6 \mathrm{mg}$ (Krisp \& Maier 2005) and that, at high temperatures and high prey density, one adult gammarid specimen consumed up to 9 (D. villosus) and 7.5 (G. roeselii) chironomid larvae per day, respectively, one could speculate that one gammarid can consume biomasses per day in the range of $1 / 2$ to $1 / 3$ of its own biomass. Yet, this is a rough estimate, which has to be tested by further investigations. Considering this estimation one should note that gammarids are not simply predators but omnivores feeding on plants, detritus and live and dead animals (e.g., Ponyi 1956, 1961; MacNeil et al. 1997; Platvoet et al. 2006; Mayer et al. 2008). This plasticity in feeding mode, which may vary from species to species (Mayer et al. 2009), may be one reason for the success of these animals in freshwaters.

\section{ACKNOWLEDGEMENTS}

This study was part of the project "Aquatische Neozoen im Bodensee und seinen Zuflüssen" (ANEBO) supported by the European Union within the scope of the Interreg III A-Programme "Alpenrhein-BodenseeHochrhein". We are grateful for this support. Particular thanks go to two anonymous reviewers for their valuable critical comments on an earlier draft of this manuscript.

\section{REFERENCES}

Bärlocher, F. \& B. Kendrick. 1973. Fungi and food preferences of Gammarus pseudolimnaeus. Arch. Hydrobiol., 72: 501-516.

Bij de Vaate, A. \& A. G. Klink. 1995. Dikerogammarus villosus Sowinsky (Crustacea: Gammaridae) a new immigrant in the Dutch part of the Lower Rhine. Lauterbornia, 20: 51-54.
Bollache, L. 2004. Dikerogammarus villosus (Crustacea: Amphipoda): another invasive species in Lake Geneva. Revue Suisse de Zoologie, 111: 309-313.

Bollache, L., S. Devin, R. Wattier, M. Chovet, J.-N. Beisel, J.C. Moreteau \& T. Rigaud. 2004. Rapid range extension of Ponto-Caspian amphipod Dikerogammarus villosus in France: potential consequences. Arch. Hydrobiol., 160: 57-66.

Casellato, S., G. La Piana, L. Latella \& S. Ruffo. 2006. Dikerogammarus villosus (Sowinsky, 1894) (Crustacea, Amphipoda, Gammaridae) for the first time in Italy. Italian Journal of Zoology, 73: 97-104.

Cummins, K. W. \& M. J. Klug. 1979. Feeding ecology of stream invertebrates. Annual Review of Ecology and Systematics, 10: 147-172.

Dick, J.T.A. 1996. Post-invasion amphipod communities of Lough Neagh, Northern Ireland: Influence of habitat selection and mutual predation. J. Anim. Ecol., 65: 756-767.

Dick, J.T.A. \& D. Platvoet. 1996. Intraguild predation and species exclusions in amphipods: The interaction of behaviour, physiology and environment. Freshwat. Biol., 36: 375-383.

Dick, J.T.A. \& D. Platvoet. 2000. Invading predatory crustacean Dikerogammarus villosus eliminates both native and exotic species. Proceedings of the Royal Society of London B, 267: 977-983.

Dick, J.T.A., D. Platvoet \& D. W. Kelly. 2002. Predatory impact of the freshwater invader Dikerogammarus villosus (Crustacea: Amphipoda). Can. J. Fish. Aquat. Sci., 59: 1078-1084.

Gergs, R. \& K.-O. Rothhaupt 2008. Feeding rate, assimilation efficiencies and growth of two amphipod species on biodeposited material from zebra mussels. Freshwat. Biol., 53; 2494-2503.

Grabow, K., T. O. Eggers \& A. Martens. 1998. Dikerogammarus villosus Sovinsky (Crustacea: Amphipoda) in navigable canals and rivers of northern Germany. Lauterbornia, 33: 103-107.

Haeckel, J.-W., M.P.D. Meijering \& H. Rusetzki. 1973. Gammarus fossarum Koch als Fallaubzersetzer in Waldbächen. Freshwat. Biol., 3: 241-249.

Kinzler, W. \& G. Maier 2003. Asymmetry in mutual predation: possible reason for the replacement of native gammarids by invasives. Arch. Hydrobiol., 157: 473-481.

Kinzler, W. \& G. Maier. 2006. Selective predation by fish: a further reason for the decline of native gammarids in the presence of invasives. J. Limnol., 65: 27-34.

Kley, A. \& G. Maier. 2003. Life history characteristics of the invasive freshwater gammarids Dikerogammarus villosus and Echinogammarus ischnus in the River Main and the Main-Donau canal. Arch. Hydrobiol., 156: 457-469.

Kley, A. \& G. Maier. 2006. Reproductive characteristics of invasive gammarids in the Rhine-Main-Danube catchment, South Germany. Limnologica, 36: 79-90.

Kostalos, M. \& R.L. Seymour. 1976. Role of microbial enriched detritus in the nutrition of Gammarus minus (Amphipoda). Oikos, 27: 512-516.

Krisp, H. \& G. Maier. 2005. Consumption of macroinvertebrates by invasive and native gammarids: a comparison. $J$. Limnol., 64: 55-59.

Lods-Crozet, B. \& O. Reymond. 2006. Bathymetric expansion of an invasive gammarid (Dikerogammarus villosus, Crustacea, Amphipoda) in Lake Leman. J. Limnol., 65: 141-144.

Maazouzi, C., G. Mason, M. Soledad Izquiero \& J.-C. Pihan. 2007. Fatty acid composition of the amphipod Dikerogammarus villosus: Feeding strategies and trophic links. Comparative Biochemistry and Physiology, Part A, 147: 868-875.

MacNeil, C., J.T.A. Dick \& R.W. Elwood. 1997. The trophic ecology of freshwater Gammarus spp. (Crustacea: Am- 
phipoda): Problems and perspectives concerning the functional feeding group concept. Biol. Rev., 72: 349-364.

Marguillier, S. 1998. Stable isotope ratios and food web structure of aquatic ecostystems. Thesis, Vrije Universiteit Brussel.

Mayer, G., G. Maier, A. Maas \& D. Waloszek. 2008. Mouthparts of the Ponto-Caspian invader Dikerogammarus villosus (Amphipoda: Pontogammaridae). Journal of Crustacean Biology, 28: 1-15.

Mayer, G., G. Maier, A. Maas \& D. Waloszek. 2009. Mouthpart morphology of Gammarus roeselii compared to a successful invader, Dikerogammarus villosus (Amphipoda): Journal of Crustacean Biology, 29: 161-174.

Mürle, U., A. Becker \& P. Rey. 2004. Dikerogammarus villosus (Amphipoda) new in Lake Constance. Lauterbornia, 49: 77-79.

Platvoet, D., J.T.A. Dick, N. Konijendijk \& G. Van der Velde. 2006. Feeding on micro-algae in the invasive PontoCaspian amphipod Dikerogammarus villosus (Sovinsky, 1894). Aquat. Ecol., 40: 237-245.

Pöckl, M. 1993. Beiträge zur Ökologie des Bachflohkrebses (Gammarus fossarum) und Flußflohkrebses (Gammarus roeseli). Entwicklungszyklus und Fortpflanzungskapazität. Natur und Museum, 423: 114-125.

Pöckl, M. 1995. Laboratory studies on growth, feeding, moulting and mortality in the freshwater amphipods Gammarus fossarum and G. roeseli. Arch. Hydrobiol., 134: 223-253.

Received: September 2010

Accepted: December 2010
Pöckl, M. 2007. Strategies of a successful invader in European freshwaters: fecundity and reproductive potential of the Ponto-Caspian amphipod Dikerogammarus villosus in the Austrian Danube, compared with the indigenous Gammarus fossarum and G. roeseli. Freshwat. Biol., 52: 50-63.

Ponyi, E. 1956. Ökologische, ernährungsbiologische und systematische Untersuchungen an verschiedenen GammarusArten. Arch. Hydrobiol., 52: 367-387.

Ponyi, E. 1961. Über die Ernährung einiger Amphipoden (Crustacea) in Ungarn. Annales Instituti Biologici (Tihany) Hungaricae, 28: 117-123.

Roberts, G.M. 1995. Salt marsh crustaceans, Gammarus duebeni and Palaemonectes varians as predators of mosquito larvae and their reaction to Bacillus thuringensis subsp. israelensis. Biocontrol Science and Technology, 5: 379-385.

Van der Velde, G., R.S.E.W Leuven, D. Platvoet, K. Bacela, M.A.J. Huijbregts, H.W.M. Hendriks \& D. Kruijt. 2009. Environmental and morphological factors influencing predatory behaviour by invasive non-indigenous gammaridean species. Biol. Invasions, 11: 2043-2054.

Van Riel, M.C., G. Van der Velde, S. Rajagopal, S. Marguillier, F. Dehairs \& A. Bij de Vaate 2006. Trophic relationships in the Rhine food web during invasion and after establishment of the Ponto-Caspian invader Dikerogammarus villosus. Hydrobiologia, 565: 39-58. 